SUMMARY OF SELECTED AEC CONTRACTOR

ENVI RONMENTAL SURVEILLANCE

TECHNIQUES AND CAPABILITIES
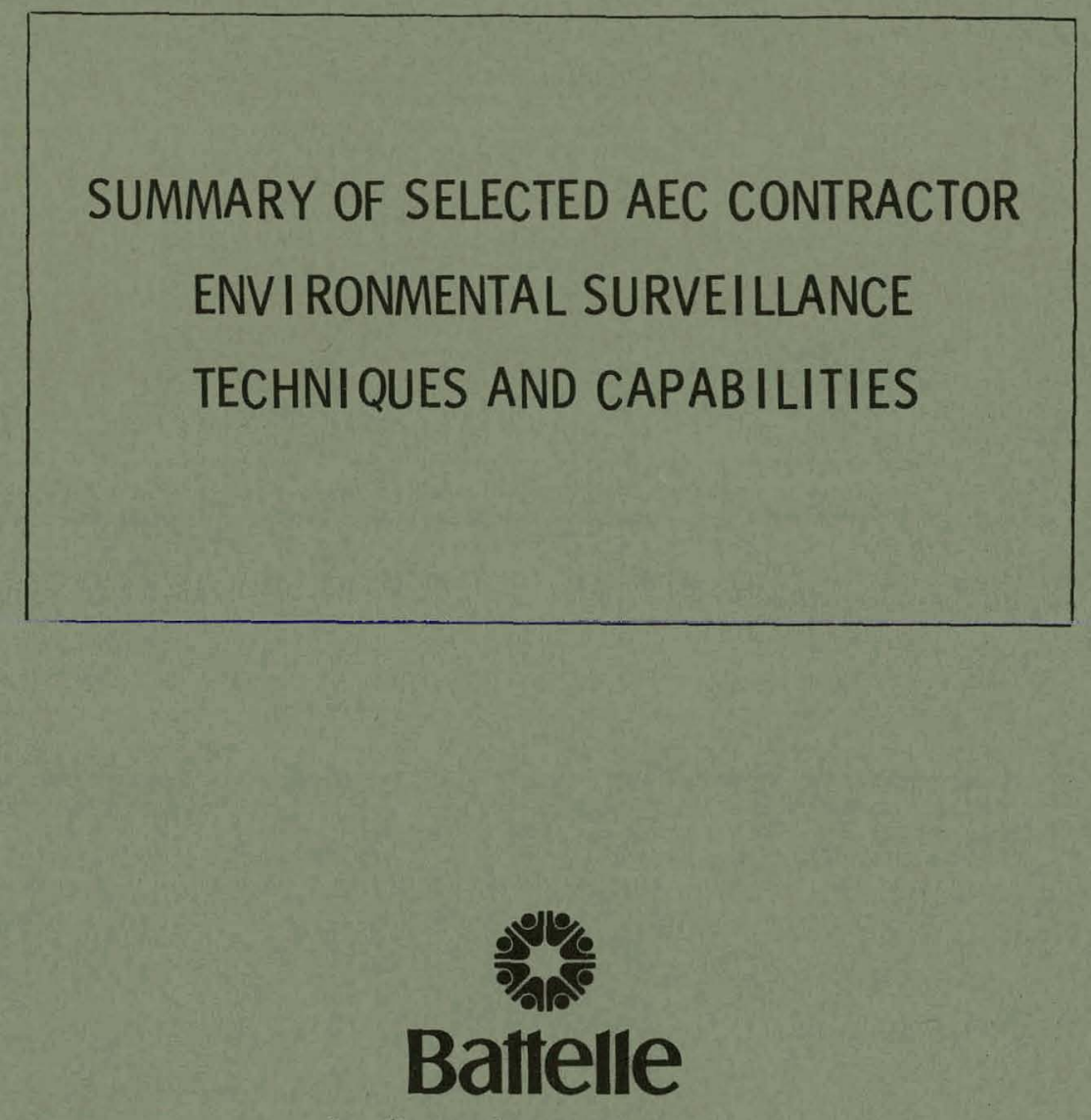

Pacific Northwest Laboratories

Richland, Washington 99352

SEPTEMBER 1974

Prepared for the U.S. Atomic Energy

Commission under Contract AT(45-1):1830 


\section{DISCLAIMER}

This report was prepared as an account of work sponsored by an agency of the United States Government. Neither the United States Government nor any agency Thereof, nor any of their employees, makes any warranty, express or implied, or assumes any legal liability or responsibility for the accuracy, completeness, or usefulness of any information, apparatus, product, or process disclosed, or represents that its use would not infringe privately owned rights. Reference herein to any specific commercial product, process, or service by trade name, trademark, manufacturer, or otherwise does not necessarily constitute or imply its endorsement, recommendation, or favoring by the United States Government or any agency thereof. The views and opinions of authors expressed herein do not necessarily state or reflect those of the United States Government or any agency thereof. 


\section{DISCLAIMER}

Portions of this document may be illegible in electronic image products. Images are produced from the best available original document. 


\section{NOTICE}

This report ivas prepared as an account of work sponsored by the United States Government. Neither the United States nor the United States Atomic Energy Commission, nor any of their employees, nor any of their contractors, subcontractors, or thier employees, makes any warranty, express or implied, or assumes any legal liability or responsibility for the accuracy, completeness or usefulness of any information, apparatus, product or process disclosed, or represents that its use would not infringe privately owned rights.

\section{PACIFIC NORTHWEST LABORATORY operated by \\ BATTELLE \\ for the \\ U.S. ATOMIC ENERGY COMMISSION}

Under Contract AT(45-1)-1830 


\title{
SUMMARY OF SELECTED AEC CONTRACTOR ENVIRONMENTAL SURVEILLANCE TECHNIQUES AND CAPABILITIES
}

\author{
D.H. Denham \\ D.A. Waite \\ J.P. Corley
}

\section{Sep̀tember 1974}

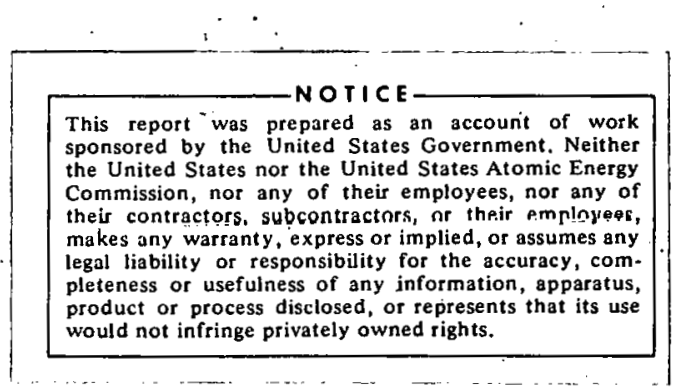

BATTELLE

PACIFIC NORTHWEST LABORATORIES

RICHLAND, WASHINGTON 99352 
SUMMARY OF SELECTED AEC CONTRACTOR ENVIRONMENTAL SURVEILLANCE TECHNIQUES AND CAPABILITIES

D. H. Denham*, D. A. Waite and J. P. Corley September 1974

\section{INTRODUCTION}

The Atomic Energy Commission, through its Division of Operational Safety, has provided funding to Battelle-Pacific Northwest Laboratories to conduct a study to:

1. Delineate the capabilities and limitations of the various effluent and environmental monitoring systems for radioactivity currently used by AEC contractors.

2. Provide recommended standard methods and procedures to bring uniformity and comparability to AEC contractor environmental monitoring and reporting systems.

3. Provide the Division of Operational Safety with a draft handbook of environmental monitoring procedures.

The objectives of the first phase of this study were to: (1) determine the capabilities and limitations of environmental radiation monitoring methods, and reporting procedures currently in use by AEC contractors; (2) identify the component parts of a total program; and (3) identify where additional guidance is needed for comparability.

This report summarizes the results of this survey of existing environmental surveillance procedures at 19 major AEC installations, and provides benchmarks for future recommendations concerning standardization of comparable methods and procedures for environmental monitoring and reporting. It should be emphasized throughout this report that, while the information gathered relates to both effluent and environmental

*Currently employed by Radiation Management Corporation, Philadelphia, Pennsylvania 
monitoring, the latter is emphasized here. Information on effluent monitoring was used only as it amplified environmental surveillance programs or was deemed necessary for estimation of radiation doses to persons living in the environs of the facility. However, the data collected on effluent monitoring systems at the sites visited has been compiled and is shown in a series of tables as Appendix $B$ to this report. No attempt was made to. categorize the many effluent streams at the sites, but only those considered typical and most significant in terms of potential environmental effect.

The goals for the next phase of this study are to: (a) in consultation experts on various aspects of environmental monitoring, define recommended and accepted procedures for the various categories of environmental surveillance at $A E C$ installations; (b) provide a discussion of the various surveillance methods with a view toward specifying the capabilities, limitations and conclusions that one would expect from such surveillance techniques; and (c) incorporate these details and guidance into a Handbook. It is expected that such a Handbook will provide a reference to assist Headquarters and field office and contractor management and staff in evaluating and comparing environmental monitoring and reporting programs at AEC contractor facilities.

\section{Information Gathering}

To determine current effluent and environmental monitoring capabilities, a comprehensive discussion outline (Appendix) was developed. A copy of the discussion outiine was sent in advance to each site to help prepare for the site visit and ensuing discussion. Concurrentiy, telephone contacts were made with each of the AEC Operations Offices. Following these telephone contacts, visits were scheduled with health physics and environmental evaluations personnel at the AEC installations. The group of AEC installations chosen to visit were selected on the basis of those whose programs would be representative of the variety and complexity of surveillance activities being conducted by AEC contractors. These contractors are listed in Table 1. 
TABLE 1. AEC Installations and Contractors Visited to Discuss Effluent and Environmental Monitoring Practices

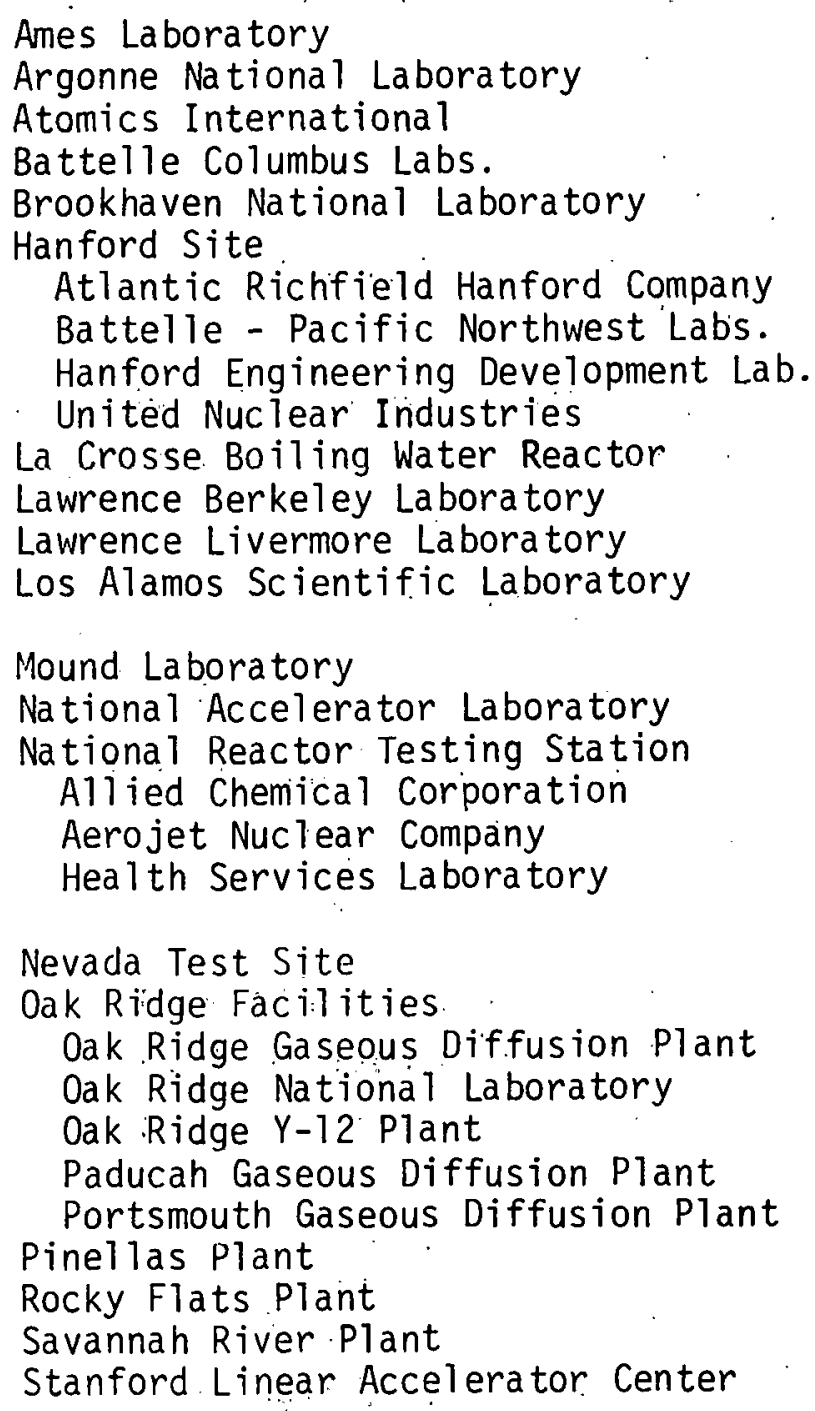

Ames, Iowa

Argonne, I11.

Canoga Park, Cal if:

Columbus, Ohio

Upton, N.Y.

Richland, Wash.

La Crosse, Wisc.

Berkeley, Cal if.

Livermore, Cal if.

Los Alamos, New Mexico

Miamisburg, Ohio

Batavia, Illinois.

Idaho Falls, Idaho

Mercury, Nevada

Oak Ridge, Tenn.

Paducah, Kentucky

Piketon, Ohio

St. Petersburg, Fla.. Golden, Colo.

Aiken, S. Carolina

Stanford, Cal ifornia 
The information collected at each site was based on surveillance programs (not research and development or specialty programs) and the information published in the respective 1972 environmental monitoring reports as compiled by the AEC.

All sites visited were classified according to the existing or anticipated radionuclide composition of their effluent streams (Table 2). This classification depends primarily upon the type of operation(s) conducted at the respective facilities and does not take into account the quantity or degree of potential for release. However, some of the obvious factors which affect the relative level of surveillance, but which are not included here, are:

1. The potential hazard of the materials being handled.

2. The extent to which facility operations are routine and unchanging.

3. The size of the total operation, since even a modest surveillance effort at a very small facility represents a significant fraction of the total operating effort.

The content of the environmental surveillance programs of the 19 sites included in this study is a function of the individual facility operations. Therefore, a brief description of the operations carried out at these facilities is given below:

Uranium and Transuranium Facilities

These process large quantities of natural and enriched uranium, and plutonium, both as oxides and metals. Included are gaseous diffusion, feed and production plant; and major weapon facilities.

Major Production and Research Facilities

These include chemical processing and radioisotope production plants, nuclear reactors, research laboratories, transuranium facilities, and support facilities. The operations at these facilities include nuclear research projects with most radionuclides. The nature, extent, and hazards of the materials involved require that much of the work be confined to hot cells and glove boxes. 
TABLE 2. Site Categorization by Effluent

No. of Sites* in Which Listed Contaminant could be Part of Effluent

Contaminant

Ga seous

Liquid.

Tritium

17

16

Noble Gas

16

Halogens.

14

14

Activation or Mixed

Fission Products

16

16

Uranium

13

14

Transuranics

13

13

*Total number of sites included in study -19 . 


\section{Research Reactors}

These are utilized for fuel and reactor development studies, irradiation of materials, and some medical applications.

Smal1 Nuclear Research Facilities

Those included here are involved in research and development activities with most radionuclides, with emphasis on the specialty areas, such as biology.

Accelerator Facilities

These are devoted to theoretical and experimental research in high energy physics. The potential environmental problems are the release of noble or activation gases and external neutron and gamma radiation.

\section{Power Reactors}

Those included here are located on river sites where waterborne nuclides and airborne noble gases represent the primary environmental surveillance problems.

For the 19 sites visited, 28 individual contractors were represented. The number of contractor facilities represented by each of the above categories are i isted in Table 3 .

TABLE 3. Classification of Facilities Visited

Type of Facility

Uranium and Transuranium

Major Production and Research

Research Reactor

Nuclear Research

Accelerator

Power Reactor
Number of Facilities

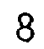

6

6

3

3

2 
Terminology

In this report the following terminology has been used: DETECT. means to determine the presence of radiation or radioactivity while MEASURE means to determine the quantity. MONITORING is defined as the periodic or continuous surveillance of the radiation level or quantity of radioactive material present. This can be accomplished by periodic instrument surveys or by a radiation detector whose signal is recorded, such as an air monitor or an ambient gamma background monitor. To SAMPLE means to remove a portion of an environmental medium for future analysis, typically in a laboratory. The sample can be CONTINUOUS or GRAB. The sample is PROPORTIONAL if a known fraction of the medium is withdrawn and it is REPRESENTATIVE if the sample withdrawn has the same characteristics as the source.

\section{RESULTS}

The environmental surveillance techniques in use by the various AEC contractors, as determined from the si.te visits, discussions, and 1972 annual reports, are summarized in. Tables 4 through 16. In general, the environmental surveillance programs were divided into two geographical areas: onsite, which includes the area between the security fences surrounding each operating facility and the site boundaries; and offsite, which is the area beyond the property boundaries of the respective sites.

For each environmental medium, only those parameters considered to have the most influence on data evaluation are presented in the summary tables. These parameters include sampling rationale, location, medium, collection (and analytical, if different) frequency, sample handling or preparation., and analysis. Since data handling and interpretation typically were unique to each site, the results thereof are shown separately in. Table 17.. . Under the title of each table is shown the number of sites (19 maximum) collecting that type of sample. The number of those particular si.tes whose methods, etc. match the listed categories are shown in the respective columns. In a number of instances more than one parameter applied at a given. site, e.g. more than one rationale statement applied to the collection of air samples, samples were collected 
at more than a single location, and more than one analysis was performed on each sample. Thus, the sum of the tabulated values in any given table frequently exceeds the total number of sites shown at the top.

In addition to the routine sampling and analytical methods shown in Tables 4 through 16, several novel or unique methods were observed which are specifically listed below for future reference:

1. Collecting airborne tritium oxide by immersing a metal (aluminum) strip in a thermos bottle containing liquid nitrogen. ${ }^{(2)}$

7. llsing a freepe-dry technique to collect tritium nxide from various solid media. (3)

3. Collecting environmental noble gas samples in an evacuated marinelli beaker followed by gamma ray spectrometry.

4. Using a hypodermic needle in a weighted polyethylene jug to obtain an integrated water sample. (4)

5. Analyzing for plutonium in environmental samples by $a$ liquid scintillation technique. ${ }^{(5)}$

\section{DISCUSSION OF RESULTS}

The results, as expected, indicate striking variations in the relative surveillance efforts within the wide spectrum of operations considered. Variations in effort between similar facilities were, however, generally not significant. At most sites sampling of surface water, air particulates, and vegetation is conducted and direct radiation is measured in the environs. Since only two sites reported routine collection of noble gases, and two reported meat or poultry sampling, these items are not reported in the tables. Otherwise, all media which are routinely sampled at more than two sites have been included in the summary tables.

Although the choice of distances in the "location" column was arbitrary, the overwhelming majority of environmental samples are collected either onsite or within 10 miles of the respective site boundaries. Most sites also utilize "background" stations for the 
collection of several media. These are often located more than 50 miles from the site. The routine sampling at these background and other distant sites is commonly performed by others and samples are shipped to the respective laboratories for analysis. Only two of the 19 sites reported the analysis of their samples was performed by an independent laboratory.

Based on this study it is our contention that while the selection of sampling equipment and the techniques used to collect environmental samples are important, the evaluation of the resulting analytical data are of even greater importance. The choice of sampling equipment, methods of sample preparation, and counting instruments are dependent on the radionuclides involved and their relative concentrations. Table 18 summarizes the routine detection capabilities for the various environmental nuclide/medium combinations reported by the 19 sites (Tables 4 through 16). With samples being analyzed by several different laboratories, it is necessary that similar detection capabilities be available to assure comparability.

The greatest diversity between facilities in areas related to environmental surveillance were for meteorology and dose evaluation. Several major installations reported rather sophisticated meteorological data collection systems, i.e. the capability to measure wind speed, wind direction, and temperature at several elevations and at several locations within the site boundary. At two sites the data are telemetered to a central location where dispersion calculations can be made in the event of an accident. On the nther hand, most of the smaller sites rely on meteorological data collected offsite at a local airport or weather bureau station.

Estimates of population dose based on effluent releases were published in the 1972 annual reports of most of the sites considered here. Typically, these calculations were only a product of the appropriate annual dose limit for the critical organ (e.g. 500 or 1,500 mrem) and the ratio of calculated concentrations in air or water to the respective MPC. At none of the sites visited were estimates of individual 
or population dose based solely on environmental data. This is not wholly unexpected since the direct measurement of external dose or concentrations of radionuclides in environmental media attributable to the discharge of radionuclides from normal operations are often masked by variations in natural background levels. Except for the direct radiation pathway, most environmental dose estimates were based on effluent data and theoretical calculations of dispersion (air) or dilution (water) and standard man inhalation or ingestion parameters as appropriate.

\section{SUMMARY}

The radiological environmental surveillance procedures used at 19 major AEC contractor sites---including 8 uranium and transuranium facilities, 6 major production and research facilities, 6 research reactors, 3 nuclear research facilities, and 2 power reactors---were reviewed. A wide variation was observed in the types, capabilities, and radiological evaluation techniques currently practiced for routine environmental survei.l lance.

No glaring deficiencies were noted at any of the sites visited. However, the fact that variation from site to site in sampling, analysis, and data handling was the rule rather than the exception, indicates the need for definitive performance criteria.

These criteria should provide a sound basis to define the specific rationale for media, location, and frequency; for minimum acceptable detection limits; and for data handling and reporting. Specific items requiring further research or study are listed below under the same subheadings as shown in Tables 4 through 16 . Concern for a number of these items was expressed during the site visits and discussions.

\section{EVALUATION}

The identification and priority ranking of environmental surveillance areas needing additional research or decisions were accomplished by involving the site visitation teams in a three-step evaluation process. 
First, each site visitor was asked to register his evaluation of site-to-site comparability of rationale, sampling, analysis and interpretation aspects of environmental surveillance by rating from 1 to 4 each combination included in Table 19. Based on printed reports and experiences at the visited sites, the consensus is indicated in Table 19. The column and row totals were included to indicate nuclide/medium combinations.or aspects of environmental surveillance which may warrant special attention from the outset. This tabulation also reveals which surveillance aspects are comparable and which are not, which have the most problems and which are the most refined.

Table 20 represents the relative importance of sampling specific environmental nuclide/medium combinations, considering typical yearly releases from nuclear facilities and potential exposure pathways, based on probable importance as a trend indicator, or as a source of population dose. The greatest importance of any combination is reflected by a relative importance factor of 5 in the lefthand column and a 1 reflects least importance.

By combining the results of Tables 19 and 20, a ranking of needs for additional guidance or research, based on comparability evaluations, is obtained as weighted by relative dose importance results. Table 21 , therefore, indicates in a task unspecific fashion the priorities on which environmental surveillance problems should be attacked. As an example, this tabulation suggests that since noble gas releases to the environs of AEC installations represent the major dose pathway to man and also has a relatively low comparability rating, it should have top investigational priority for providing additional guidance.

Extending this procedure and utilizing the data from the Tables 19-21, a list of priority needs was derived. This list (Table 22) encompasses rationale, methodology, analysis and interpretation of data relating principally to direct radiation, atmospheric tritium, aquatic and terrestrial biota, soil and decomipusition. 


\section{REFERENCES}

1. U.S. Atomic Energy Commission, Environmental Monitoring at Major U.S. Atomic Energy Commission Contractor Sites - CY-1972, WASH1259, compiled by the Division of Operational Safety, Aug., 1973.

2. T. B. Rhinehammer and P. H. Lamberger, Tritium.Control Technology, WASH-1269, p. 75, December 1973.

3. T. Hawkinson, et al., Ecological Inventory of Radioactive Materials in Waste Discharge Areas at Los Alamos Scientific Laboratory, LA-5282-MS, 1973.

4. J. A. Zillich; J. Truchan, and J. Hesse, "Techniques Involved in Sampling and Interpreting Ecological Impact in a Watershed," Water-1973, J. F. Bennett (ed), AICE Symposium Series \#136, voT. 70, T974.

5. D. L. Bokowski, Liquid Scintillation Counting for Plutonium in Environmental Samples, RFP-2037, Dow Chemical USÄ, Rocky Flats Div., Golden, Colorado, March 14, 1973. 
TABLE 4. Summary of Environmental Surveillance Techniques at Selected AEC Contractor Installations-Air, Particulates

(15 Sites)

\begin{tabular}{|c|c|c|}
\hline $\begin{array}{c}\text { Basis for } \\
\text { Sample Location }\end{array}$ & $\begin{array}{l}\text { No. of } \\
\text { Sites }\end{array}$ & Location \\
\hline $\begin{array}{l}\text { Meteorology } \\
\text { Demography } \\
\text { Surround. Site } \\
\text { Power Available }\end{array}$ & $\begin{array}{r}6 \\
4 \\
11 \\
13\end{array}$ & $\begin{array}{l}\text { On-Site } \\
\text { Perimeter } \\
0-5 \text { Miles } \\
5-10 \text { Miles } \\
10-50 \text { Miles } \\
\text { Over } 50 \text { Miles }\end{array}$ \\
\hline
\end{tabular}

\begin{tabular}{|c|}
\hline $\begin{array}{l}\text { No. of } \\
\text { Sites } \\
\end{array}$ \\
\hline $\begin{array}{rc}12 & (10) * \\
11 & (6) \\
6 & (8) \\
4 & (4) \\
8 & (5) \\
4 & (3)\end{array}$ \\
\hline
\end{tabular}

Orientation
One Meter
Over One Meter
Horizontal
Vertical Down
Vertical Up

\begin{tabular}{l} 
No. of \\
Sites \\
\hline 11 \\
3 \\
4 \\
6 \\
2
\end{tabular}

\begin{tabular}{lc}
$\begin{array}{c}\text { Sample } \\
\text { Preparation }\end{array}$ & $\begin{array}{c}\text { No. of } \\
\text { Sites }\end{array}$ \\
\cline { 1 - 1 } None & \\
Composite & 9 \\
Dissolve & 4 \\
Leach: & 2 \\
&
\end{tabular}

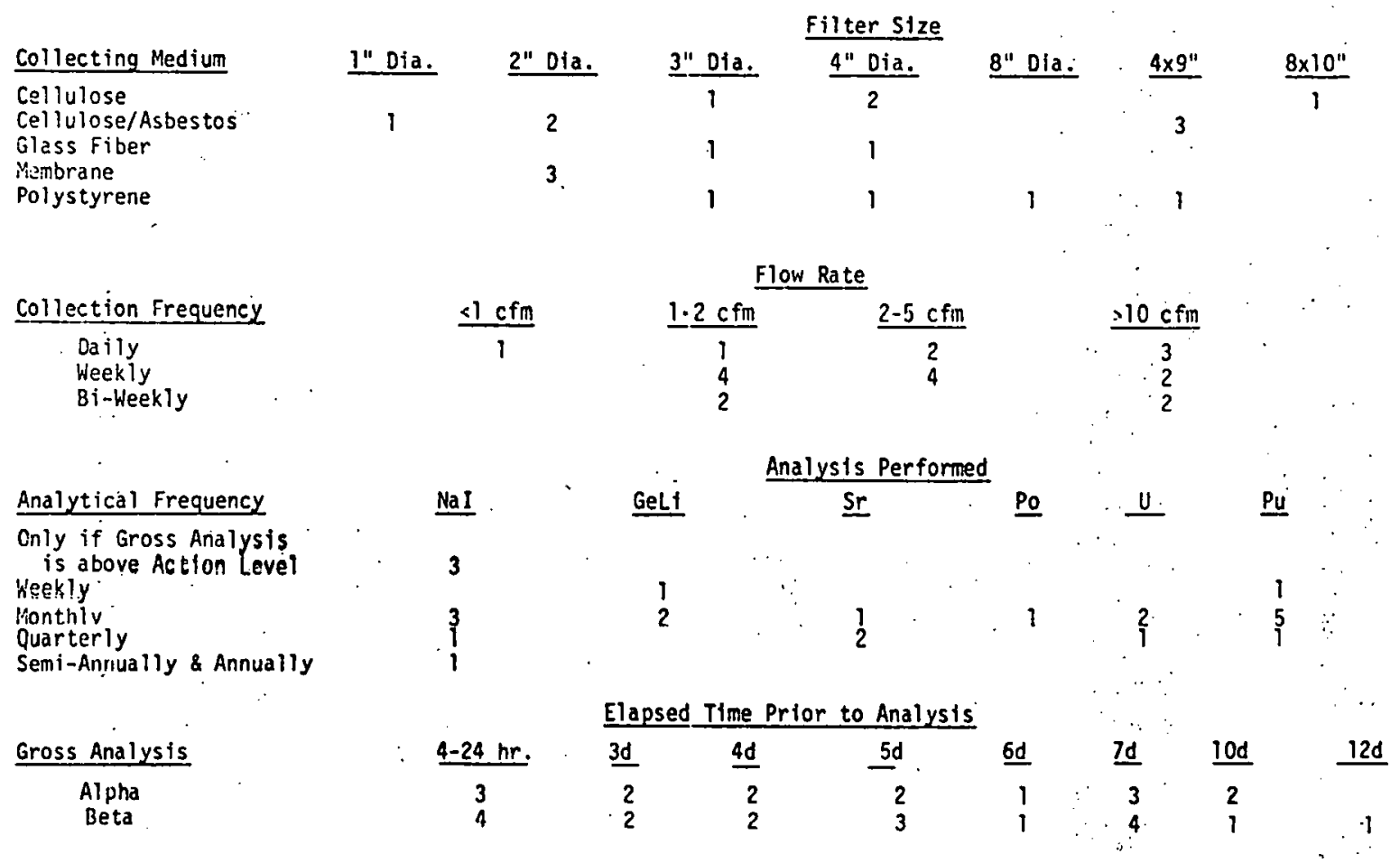

Number shown in parentheses represents the average number of samplers located within given range per site. 
TABLE 5. Summary of Environmental Surveillance Techniques at Selected A.EC Contractor Instaliations-Air, Iodine

(9 Sites)

\begin{tabular}{|c|c|c|c|c|c|c|c|}
\hline $\begin{array}{l}\text { Basis for } \\
\text { Sample Location }\end{array}$ & $\begin{array}{l}\text { No. of } \\
\text { Sites }\end{array}$ & Location & $\begin{array}{l}\text { No. of } \\
\text { Sites }\end{array}$ & $\begin{array}{c}\text { Sample: } \\
\text { Analysis } \\
\end{array}$ & $\begin{array}{l}\text { No. of } \\
\text { Sites }\end{array}$ & $\begin{array}{l}\text { Collecting } \\
\text { Medium } \\
\end{array}$ & $\begin{array}{l}\text { No. of } \\
\text { Sites }\end{array}$ \\
\hline
\end{tabular}

Flow Rate

Collection Frequency

Daily

Weekly

Bi-Weekly

$\frac{1 \mathrm{cfm}}{1}$

1

$\begin{array}{ccc}<1-2 \mathrm{cfm} & \frac{2-5 \mathrm{cfm}}{2} & \frac{210 \mathrm{cfm}}{2} \\ 3 & 2 & 1 \\ 1 & 1 & \end{array}$

ॠNumber shown in parent leses represents the average number of samplers located within given range per site.

${ }^{+}$Not routinely analyzed. 
TABLE 6. Summary of Environmental Surveillance Techniques at Selected AEC Contractor Installations-Air, Tritium

(7 Sites)

\begin{tabular}{|c|c|c|c|c|c|c|c|}
\hline $\begin{array}{c}\text { Basis for } \\
\text { Sample Location } \\
\end{array}$ & $\begin{array}{l}\text { No. of } \\
\text { Sites }\end{array}$ & Location & $\begin{array}{l}\text { No of } \\
\text { Sites }\end{array}$ & $\begin{array}{l}\text { Collection } \\
\text { Medium } \\
\end{array}$ & $\begin{array}{l}\text { No. of } \\
\text { Sites } \\
\end{array}$ & $\begin{array}{l}\text { Sample Prep. } \\
\& \text { Analysis } \\
\end{array}$ & $\begin{array}{l}\text { No. of } \\
\text { Sites }\end{array}$ \\
\hline $\begin{array}{l}\text { Meteorology } \\
\text { Surround. Site } \\
\text { Power Available } \\
\text { Patrway to Man } \\
\text { Background }\end{array}$ & $\begin{array}{l}2 \\
2 \\
3 \\
5 \\
1\end{array}$ & $\begin{array}{l}\text { On-Site } \\
\text { Perimeter } \\
0-5 \text { Miles } \\
5-10 \text { Miles } \\
10-50 \text { Miles } \\
\text { Over. } 50 \text { Miles }\end{array}$ & $\begin{array}{l}6(4)^{\star} \\
5(4)^{*} \\
2(8) \\
2(3) \\
2(7) \\
2(1)\end{array}$ & $\begin{array}{l}\text { Cryogenic } \\
\text { Silica gel } \\
\text { Ethylene glycol } \\
\text { Molecular Sieve } \\
\text { Evaluation Chamber }\end{array}$ & $\begin{array}{l}1 \\
4 \\
1 \\
1 \\
1\end{array}$ & $\begin{array}{l}\text { Distillation } \\
\text { Electrolysis } \\
\text { Liquid Scin- } \\
\text { tillation }\end{array}$ & $\begin{array}{l}3 \\
7 \\
6\end{array}$ \\
\hline
\end{tabular}

\section{FLOW RATE}

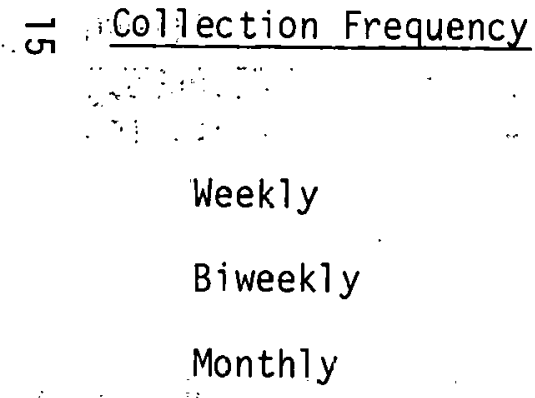

* Number shown in parentheses represents the average number of samplers located within given range per site. 
TABLE 7. Summary Jf Eivironmental Surveillance Techniques at Selected $A \equiv$ C Contractor Installations-Milk

\begin{tabular}{|c|c|c|c|c|c|}
\hline $\begin{array}{c}\text { Basis for } \\
\text { Sample Location }\end{array}$ & $\begin{array}{l}\text { No. of } \\
\text { Sites }\end{array}$ & Locatior: & $\begin{array}{l}\text { No. of } \\
\text { sites }\end{array}$ & $\begin{array}{c}\text { Collection } \\
\text { Medium }\end{array}$ & $\begin{array}{l}\text { No. of } \\
\text { Sites }\end{array}$ \\
\hline $\begin{array}{l}\text { Meteorology } \\
\text { Surround. Site } \\
\text { Nearest Farm/ } \\
\text { Dairy } \\
\text { Background Site }\end{array}$ & $\begin{array}{l}2 \\
3 \\
9 \\
1\end{array}$ & $\begin{array}{l}0-5 \text { Miles } \\
5-10 \text { Miles } \\
10-50 \text { Miles } \\
\text { Over } 50 \text { Miles }\end{array}$ & $\begin{array}{l}3 \\
4 \\
5 \\
2\end{array}$ & $\begin{array}{l}\text { Raw Milk } \\
\text { Processed Milk }\end{array}$ & $\begin{array}{r}110 \\
5\end{array}$ \\
\hline
\end{tabular}

\begin{tabular}{|c|c|c|}
\hline $\begin{array}{l}\text { Collection } \\
\text { Frequency }\end{array}$ & $\begin{array}{l}\text { No. of } \\
\text { Sites }\end{array}$ & Analytical Frequency \\
\hline $\begin{array}{l}\text { Weekly } \\
\text { Biweekly } \\
\text { Monthly } \\
\text { Bimonthly } \\
\text { Quarterly }\end{array}$ & $\begin{array}{l}2 \\
3 \\
6 \\
2 \\
1\end{array}$ & $\begin{array}{l}\text { Weekly } \\
\text { Biweekly } \\
\text { Monthly } \\
\text { Bimonthly } \\
\text { Quarterly } \\
\text { Semi-A.nnually }\end{array}$ \\
\hline
\end{tabular}

Soecific Analysis

No. of Sites

Biweek

Monthly

Quarterly

$\underline{H-3}$

$\begin{array}{ll}\underline{S r} & \text { Cs } \\ 1 \\ 1 \\ 3 \\ 3 \\ 1\end{array}$

$\underline{\text { CS }}$

$\underline{\mathrm{Pu}}$ 
TABLE 8. Summary of Environmental Surveillance Techniques at Selected AEC Contractor Installations-Groundwater

(10 Sites)

\begin{tabular}{|c|c|c|c|c|c|c|c|}
\hline $\begin{array}{c}\text { Basis for } \\
\text { Sample Location }\end{array}$ & $\begin{array}{l}\text { No of } \\
\text { Sites }\end{array}$ & Location & $\begin{array}{l}\text { No. of } \\
\text { Sites }\end{array}$ & $\begin{array}{l}\text { Collection } \\
\text { Frequency }\end{array}$ & $\begin{array}{l}\text { No. of } \\
\text { Sites }\end{array}$ & Analys is & $\begin{array}{l}\text { No. of } \\
\text { Sites }\end{array}$ \\
\hline $\begin{array}{l}\text { Trend Indicator } \\
\text { Pa thway to Man } \\
\text { Hydrology. } \\
\qquad \therefore \therefore \\
\therefore \\
\therefore \\
\because \cdots: \therefore\end{array}$ & $\begin{array}{r}5 \\
7 \\
3\end{array}$ & $\begin{array}{l}\text { On-Site } \\
\text { Site Perimeter } \\
\text { Point of } \\
\text { Nearest 'Jse }\end{array}$ & $\begin{array}{r}4 \\
4 \\
\because \\
7\end{array}$ & $\begin{array}{l}\text { Biweekly } \\
\text { Monthly } \\
\text { Quarterly } \\
\text { Semi-Annualiy }\end{array}$ & $\begin{array}{l}1 \\
7 \\
1 \\
5\end{array}$ & $\begin{array}{l}\text { Gross Alpha } \\
\text { Gross Beta } \\
\text { Gamma Scan } \\
\text { H-3 } \\
\text { Sr } \\
\text { Ra } \\
\text { U } \\
\text { Pu }\end{array}$ & $\begin{array}{l}7 \\
9 \\
4 \\
8 \\
3 \\
2 \\
1 \\
2\end{array}$ \\
\hline
\end{tabular}

TABLE 9. Summary of Environmental Surveillance Techniques at Selected AEC Contractor Installations-Drinking Water

(11 Sites)

Basis for
Sample Location
$\begin{aligned} & \text { Pathway to Mar } \\ & \text { Hydrology } \\ & \text { Demography }\end{aligned}$

\begin{tabular}{c} 
No. of \\
Sites \\
\hline 11 \\
7 \\
2
\end{tabular}

\begin{tabular}{lc} 
Collection Frequency & $\begin{array}{l}\text { No. of } \\
\text { Sites }\end{array}$ \\
\cline { 1 - 2 } Weekly & 3 \\
Biweekly & 4 \\
Monthly & 2 \\
Quarterly & 4 \\
Semi-Annually & 1 \\
Annually &
\end{tabular}

Analys is
Gross Alpha
Gross Beta
Gamma Scan
$\mathrm{H}-3$
$\mathrm{Sr}$
$\mathrm{Pu}$

No. of Sites

8

Annually 
TABLE 10. Summary of Environmental Surveillance Techriques at Selected AEC Contractor Installations-Sur=ace Water

(18 Sites)

\begin{tabular}{|c|c|c|c|c|c|c|c|}
\hline $\begin{array}{c}\text { Basis for } \\
\text { Sample Location }\end{array}$ & $\begin{array}{l}\text { No. of } \\
\text { Sites }\end{array}$ & Location & $\begin{array}{l}\text { No. of } \\
\text { sites }\end{array}$ & $\begin{array}{l}\text { Collect on } \\
\text { Frequency }\end{array}$ & $\begin{array}{l}\text { No. of } \\
\text { Sites } \\
\end{array}$ & $\begin{array}{c}\text { Sample } \\
\text { Preparation } \\
\end{array}$ & $\begin{array}{l}\text { No. of } \\
\text { Sites }\end{array}$ \\
\hline $\begin{array}{l}\text { Hydrology } \\
\text { Trend Indicator } \\
\text { Pathway to Man } \\
\begin{array}{l} \\
\therefore\end{array}\end{array}$ & $\begin{array}{l}10 \\
18 \\
11\end{array}$ & $\begin{array}{l}\text { Jpstream } \\
\text { Jownstream } \\
\text { 3ackground } \\
\text { Stream } \\
\text { Naste Ponds }\end{array}$ & $\begin{array}{l}8 \\
6 \\
2 \\
8\end{array}$ & $\begin{array}{l}\text { Daily } \\
\text { Weekly } \\
\text { Biweekly } \\
\text { Monthly } \\
\text { Bimonthly } \\
\text { Quarterly } \\
\text { Semi-Annually } \\
\text { Annually }\end{array}$ & 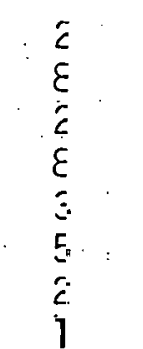 & $\begin{array}{l}\text { Pretreat Jug } \\
\text { Ion Exchange } \\
\text { Filter } \\
\text { Centrifuge } \\
\text { Evaporate } \\
\text { Composite. }\end{array}$ & $\begin{array}{r}3 \\
2 \\
4 \\
1 \\
14 \\
3\end{array}$ \\
\hline
\end{tabular}

$\vec{\infty}$

Analytical

Analysis

Frequency

Gross Alcha Gross Beta

Jamma Šcan

H-3

Sr I

Po

$\underline{\text { Ra }} \underline{\text { Th }} \underline{\mathrm{U}} \cdot \underline{\mathrm{Pu}}$

Weakly

Biweekly

Monthiy

Bimonthly

Quarterly

Semi-Annua $11 y$

Annually

6.
1
6
1
1

7
1
5
1
1

$\begin{array}{ll}2 & 2 \\ 1 & 1 \\ 3 & 4 \\ & 1 \\ i & 1\end{array}$


TABLE 11. Summary of Environmental Surveillance Techniques at Selected AEC Contractor Installations-Aquatic Biota

(6 Sites)

\begin{tabular}{|c|c|c|c|c|c|c|c|c|}
\hline $\begin{array}{c}\text { Basis for } \\
\text { Sample Location }\end{array}$ & $\begin{array}{l}\text { No. cf } \\
\text { Sites } \\
\end{array}$ & Locations: & $\begin{array}{l}\text { No. of } \\
\text { Sites }\end{array}$ & $\begin{array}{l}\text { Medium } \\
\text { Sampled } \\
\end{array}$ & $\vdots$ & $\begin{array}{l}\text { No. of } \\
\text { Sites } \\
\end{array}$ & $\begin{array}{l}\text { Sample } \\
\text { Analys is }\end{array}$ & $\begin{array}{l}\text { No. of } \\
\text { Sites }\end{array}$ \\
\hline $\begin{array}{l}\text { Pathway: to Man } \\
\text { Trend Indicator } \\
\text { Hydrology }\end{array}$ & $\begin{array}{l}6 \\
3 \\
5\end{array}$ & $\begin{array}{l}\text { Upstream } \\
\text { Downstream } \\
\text { Background } \\
\text { Stream } \\
\text { Waste Pand }\end{array}$ & $\begin{array}{l}4 \\
5 \\
1 \\
4\end{array}$ & $\begin{array}{l}\text { Fish } \\
\text { Shellfish } \\
\text { Waterfowl } \\
\text { Plants }\end{array}$ & & $\begin{array}{l}6(70)^{*} \\
1 \quad(N A)^{t} \\
2(70) \\
1(N A)\end{array}$ & $\begin{array}{l}\ddot{H}-3 \\
\mathrm{Sr} \\
U \\
\mathrm{Pu} \\
\text { Gamma Scan }\end{array}$ & $\begin{array}{l}1 \\
2 \\
1 \\
2 \\
4\end{array}$ \\
\hline
\end{tabular}

*Number shown in parentheses represerts the average number of samples collected annually of each medium per site.

${ }^{\dagger}$ Not applicable.

$\overrightarrow{6}$

TABLE 12. Summary of Environmental Surveillance Techniques at Selected AEC Contractor Installations-Sediment

(6: Sites)

\begin{tabular}{|c|c|c|c|c|c|c|c|}
\hline $\begin{array}{l}\text { Basis } \\
\text { Sample Location }\end{array}$ & $\begin{array}{l}\text { No. of } \\
\text { Sites }\end{array}$ & Location & $\begin{array}{l}\text { No. of } \\
\text { Sites }\end{array}$ & $\begin{array}{l}\text { Sampl ing } \\
\text { Frequency }\end{array}$ & $\begin{array}{l}\text { No. of } \\
\text { Sites }\end{array}$ & Analys is & $\begin{array}{l}\text { No. of } \\
\text { Sites }\end{array}$ \\
\hline $\begin{array}{l}\text {-rend Indicator } \\
\text { Hydrology } \\
\text { Pathway to Man }\end{array}$ & $\begin{array}{l}6 \\
5 \\
1\end{array}$ & $\begin{array}{l}\text { Upstream } \\
\text { Downstrećm } \\
\text { Effluent } \\
\text { Outfall }\end{array}$ & $\begin{array}{l}4 \\
5 \\
3\end{array}$ & $\begin{array}{l}\text { Monthily } \\
\text { Quarterly } \\
\text { Annually }\end{array}$ & $\begin{array}{l}1 \\
3 \\
3\end{array}$ & $\begin{array}{l}\text { Gross Alpha. } \\
\text { Gross Beta } \\
\text { Gamma Scan } \\
\text { Th, U } \\
\text { Pu }\end{array}$ & $\begin{array}{l}2 \\
2 \\
4 \\
1 \\
3\end{array}$ \\
\hline
\end{tabular}


TABLE 13. Summary of Environmental Survei1lance Teciniques at Selected AEC Contractor Installations-Soil

(13 Sites)

\begin{tabular}{|c|c|c|c|c|c|}
\hline $\begin{array}{l}\text { Basis for } \\
\text { Sample Location. }\end{array}$ & $\begin{array}{l}\text { No. Jf } \\
\text { Sites }\end{array}$ & Location & $\begin{array}{l}\text { No. of } \\
\text { Sites }\end{array}$ & $\begin{array}{l}\text { Collection } \\
\text { Frequency }\end{array}$ & $\begin{array}{l}\text { No. of } \\
\text { Sites }\end{array}$ \\
\hline $\begin{array}{l}\text { Meteoralogy } \\
\text { Surrourid. Site } \\
\text { Release Inventory } \\
\text { Trend indicator }\end{array}$ & $\begin{array}{l}3 \\
4 \\
6 \\
4\end{array}$ & $\begin{array}{l}\text { On-site } \\
\text { Perimeter } \\
0-5 \text { Miles } \\
5-10 \text { Miles } \\
10-50 \text { Miles } \\
\text { Over } 50 \text { Miles }\end{array}$ & $\begin{array}{l}7 \\
5 \\
7 \\
4 \\
2 \\
2\end{array}$ & $\begin{array}{l}\text { Monthiy } \\
\text { Quarierly } \\
\text { Semi-Annually } \\
\text { Annually } \\
1-5 \text { yr Interval }\end{array}$ & $\begin{array}{l}1 \\
2 \\
2 \\
7 \\
3\end{array}$ \\
\hline
\end{tabular}

$\tilde{\sigma}$

\begin{tabular}{|c|c|c|c|c|c|}
\hline $\begin{array}{l}\text { Sampling } \\
\text { Cepth } \\
\end{array}$ & $\begin{array}{l}\text { No. Jf } \\
\text { Sites }\end{array}$ & $\begin{array}{c}\text { Sample } \\
\text { Preparation }\end{array}$ & $\begin{array}{l}\text { No. of } \\
\text { Sites }\end{array}$ & $\begin{array}{c}\text { Number Samples/ } \\
\text { Location }\end{array}$ & $\begin{array}{l}\text { No. of } \\
\text { Sites } \\
\end{array}$ \\
\hline $\begin{array}{l}0-1 " \\
0-2 " \\
0-12 \cdot \\
0-18 \cdot \\
\text { Prof ije }\end{array}$ & $\begin{array}{l}2 \\
8 \\
4 \\
1 \\
4\end{array}$ & $\begin{array}{l}\text { None } \\
\text { Air Dry } \\
\text { Ovien Dry } \\
\text { Sieve/Screen } \\
\text { Dry Ash/Fuse } \\
\text { Leach } \\
\text { Dissoive }\end{array}$ & $\begin{array}{r}1 \\
2 \\
10 \\
4 \\
3 \\
6 \\
1\end{array}$ & $\begin{array}{r}1 \\
2 \\
5 \\
9 \\
10\end{array}$ & $\begin{array}{l}4 \\
1 \\
4 \\
2 \\
2\end{array}$ \\
\hline
\end{tabular}

Aliquot Size

Grass Alpha Gross Beta NaI GeLi $\frac{H-3}{2}$ Sr Po $\frac{\text { Th }}{1}$ U Pu

$\leq 5 \mathrm{gm}$

$10 \mathrm{gm}$

$50 \mathrm{gm}$

$100 \mathrm{gm}$

$\geq 300 \mathrm{gm}$

i

2

1

4

Analytical Technique

*A1l samples were composited (if necessary), blended, and homogenized prior to the techniques shown. 
TABLE 14. Summary of Environmental Surveillance Techniques at Selected AEC Contractor Installations-Fruits, Vegetables

( $1: 5$ sites)

\begin{tabular}{|c|c|c|c|c|}
\hline $\begin{array}{l}\text { Basis for } \\
\text { Sample Location }\end{array}$ & $\begin{array}{l}\text { No of } \\
\text { Sites }\end{array}$ & Location & $\begin{array}{l}\text { No.. of } \\
\text { Sites }\end{array}$ & $\begin{array}{l}\text { Medium } \\
\text { Sámpled }\end{array}$ \\
\hline $\begin{array}{l}\text { Pathway to Man } \\
\text { Trend Indicator } \\
\text { Meteorology } \\
\text { Surround. Site } \\
\text { Accessibility } \\
\text { Background Site }\end{array}$ & $\begin{array}{r}6 \\
15 \\
2 \\
5 \\
6 \\
3\end{array}$ & $\begin{array}{l}\text { On-Site } \\
\text { Perimeter } \\
0-5 \text { Miles } \\
5-10 \text { Miles } \\
10-50 \text { Miles } \\
\text { Over } 50 \text { Miles }\end{array}$ & $\begin{array}{r}11 \\
5 \\
7 \\
5 \\
4 \\
\quad 1\end{array}$ & $\begin{array}{l}\text { Livestock Feed } \\
\text { Produce* } \\
\text { Native Vegetation } \\
\therefore \text { (primarily grasses) } \\
\therefore \quad \therefore\end{array}$ \\
\hline
\end{tabular}

No. of

Sites

2

11

Background Site

\begin{tabular}{|c|c|c|c|c|c|}
\hline $\begin{array}{l}\text { Collection } \\
\text { Frequency }\end{array}$ & $\begin{array}{l}\text { No. of } \\
\text { Sites }\end{array}$ & $\begin{array}{c}\text { Sample } \\
\text { Preparation }\end{array}$ & $\begin{array}{l}\text { No. of } \\
\text { Sites }\end{array}$ & $\begin{array}{c}\text { Ana lytical } \\
\text { Technique }\end{array}$ & $\begin{array}{l}\text { No. of } \\
\text { Sites }\end{array}$ \\
\hline $\begin{array}{l}\text { Monthly } \\
\text { Quarterly } \\
\text { Semi-Annual ly } \\
\text { Annually }\end{array}$ & $\begin{array}{r}4 \\
5 \\
2 \\
5\end{array}$ & $\begin{array}{l}\text { None } \\
\text { Oven Dry } \\
\text { Freeze Dry } \\
\text { Alcohol Dry } \\
\text { Ash } \\
\text { Leach } \\
\text { Fuse }\end{array}$ & $\begin{array}{r}1 \\
73 \\
1 \\
1 \\
10 \\
7 \\
1\end{array}$ & $\begin{array}{l}\text { Gross Alpha } \\
\text { Gross Beta } \\
\text { Gamma Scan } \\
\mathrm{H}-3 \\
\mathrm{Sr} \\
\begin{array}{l}\mathrm{U} \\
\mathrm{Pu}\end{array}\end{array}$ & $\begin{array}{l}4 \\
4 \\
4 \\
4 \\
4 \\
4 \\
6\end{array}$ \\
\hline
\end{tabular}

*Commercially available fruits, vegetables and grains normally used for human consumption. 
TABLE 15. Summary cif Environmental Surveillance Techniques at Selected A.EC Contractor Installations-Deposition Measurements

(10 Sites)

Basis for No. of Sample Location Sites Surround. Site 1 Trend Indicator. 5 Precipitation Scavenging

\begin{tabular}{|c|c|}
\hline Location & $\begin{array}{l}\text { No. of } \\
\text { Sites }\end{array}$ \\
\hline $\begin{array}{l}\text { On-site } \\
\text { Perimeter } \\
0-5 \text { Miles } \\
\text { 10-50 Miles }\end{array}$ & $\begin{array}{l}8 \\
4 \\
1 \\
2\end{array}$ \\
\hline
\end{tabular}

$\begin{array}{lc}\text { Method } & \begin{array}{l}\text { No. of } \\ \text { Sites }\end{array} \\ & 1 \\ \text { Ground Survey } & \\ \text { Precipitaticn } & \\ \text { Collector } & 9 \\ \text { Sticky Paper } & 1 \\ \text { Fallout Tray: } & 3\end{array}$

Sampling Frequency

\begin{tabular}{|c|c|c|c|c|c|c|}
\hline Sampling Method & Per Storm & Daily & Weekly & Biwe akly & Monthly & Quarterly \\
\hline $\begin{array}{l}\text { GM Survey } \\
\text { Percipitation Collector } \\
\text { Fallout Tray (áry) } \\
\text { Sticky Paper }\end{array}$ & $\because 5$ & $\begin{array}{l}\ddots \\
\ddots \\
i \\
i\end{array}$ & $\begin{array}{l}1 \\
1\end{array}$ & $\frac{1}{1}$ & $\begin{array}{l}1 \\
2 \\
2\end{array}$ & 1 \\
\hline
\end{tabular}

Sample Handling and Preparation

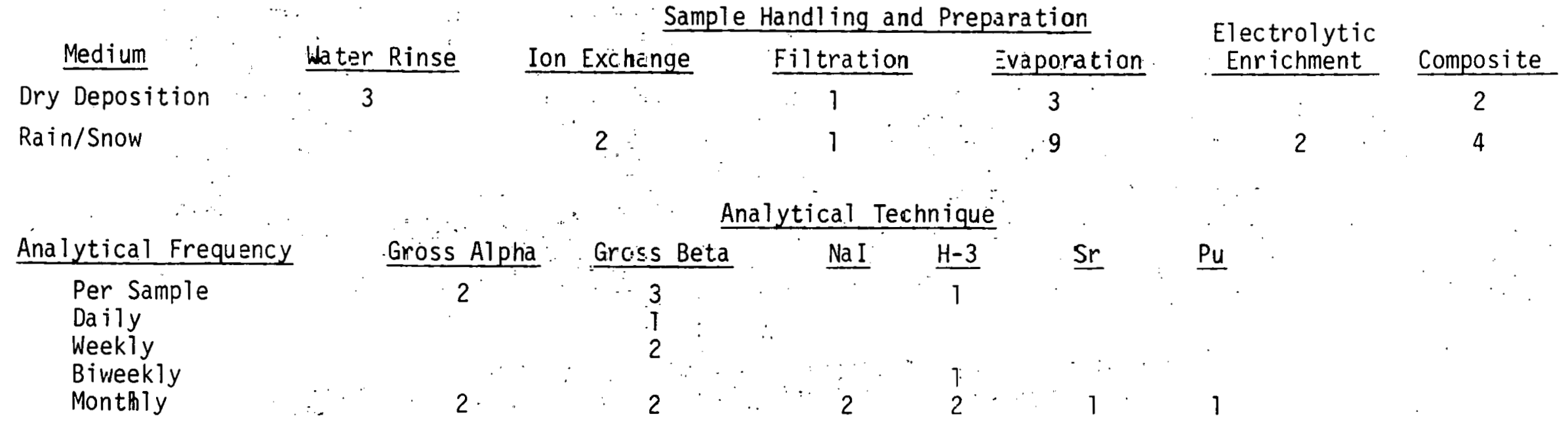


TABLE 16. Summary of Environmental Survejllance Techniques at Selected AEC Contractor Installations-Direct Radiation

(14 Sites)

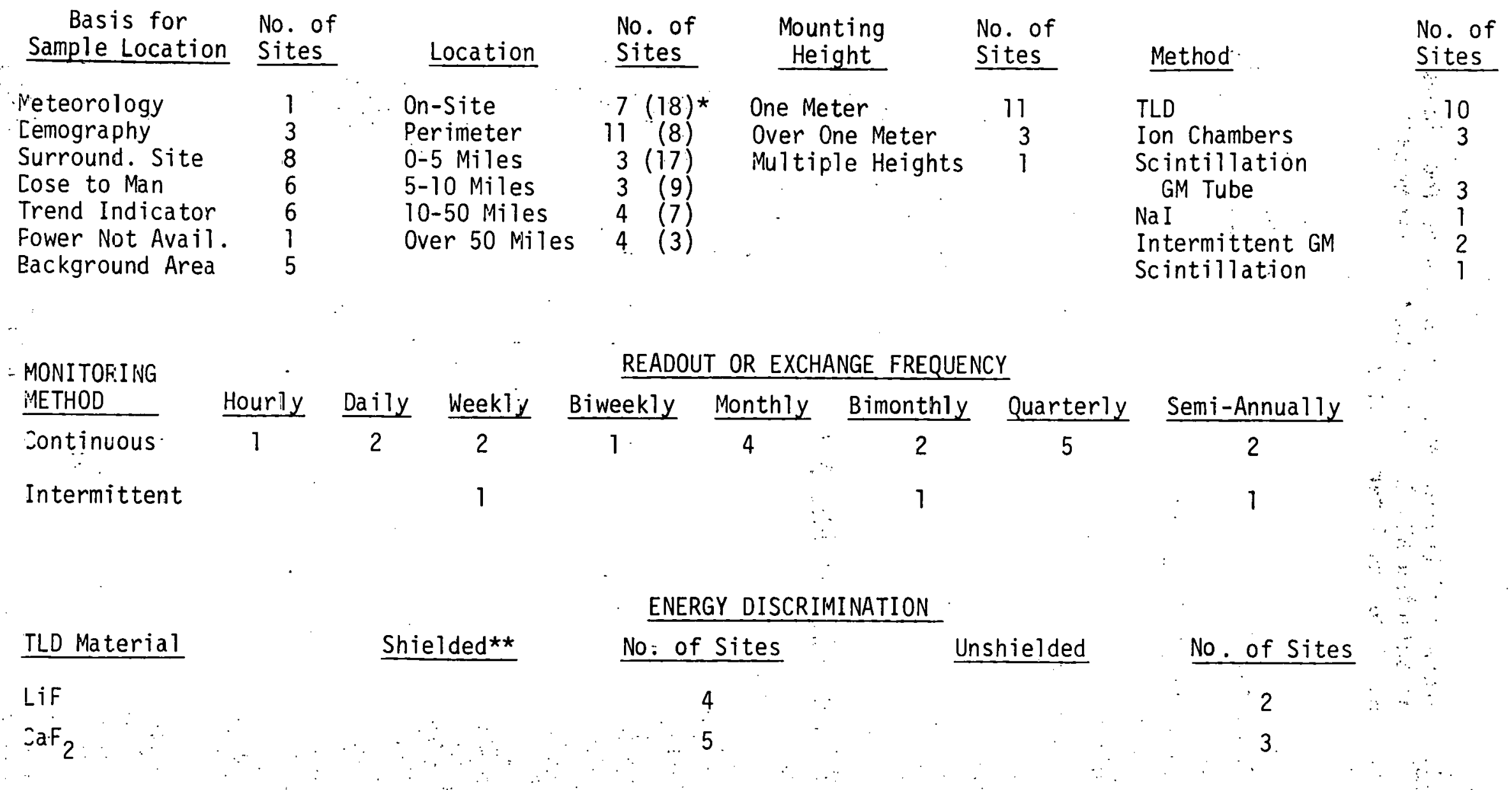

\footnotetext{
*Number shown in parentheses represents the average number of samplers located within given range per site.

**TLD's typically were encapsulated in light-and water-tight packets, the number of sites shown in the "shielded" column refer to those using one or more gamma energy filters.

Thethods shown are typically for beta-gamma external radiation. Three sites also were monitoring for fast neutrons using moderated defectors and continuous chart records.
} 
TABLE 17. Summary of Environmental Surveillance Techniques at Selected AEC Contractor Installations-Data Handling and Interpretation

Data

Handling

Statistical Evaluation

Range

Normạ 1

Log-Normal

Use

Action

Control

Handling of Less-Than Values

Zero

$\mathrm{DL}$

$1 / 2 \mathrm{DL}$

Value

other
No. of

Sites

8

3

3

3

2
1

1

1

2

1 
TABLE 18. Minimum Detection Capabiti ities for Most Common Radionuclides Observed in Environmental Samples

Media \& Nuclide(s)

Air
Gross Alpha
Gross Beta
H-3 (HTO)
I-131
Pu-238
Pu-239
Gamma Scan**

Water

Gross Alpha:

Gross Beta

H-3 (HTO)

Sr- -89

$\mathrm{Sr}-90$

I-131

Uranium

Pu-238

$\mathrm{Pu}-239$

Gamma Scan

Soil and Sediment

Gross Alpha

Gross Beta

$\mathrm{Sr}-90$

$\mathrm{Pu}-238$

$\mathrm{Pu}-239$

Gamma Scan

\section{Minimum. Detectable Level s*}

Typical $\cdots$ Range

(Units of $\mu \mathrm{Ci} / \mathrm{ml}$ )

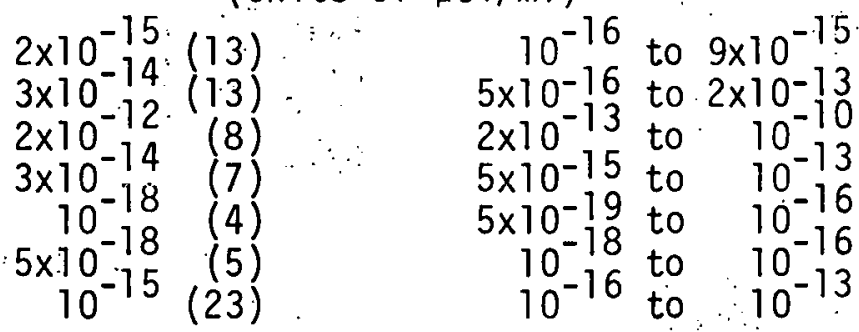

(Units of $\mu \mathrm{Ci} / \mathrm{ml}$ )

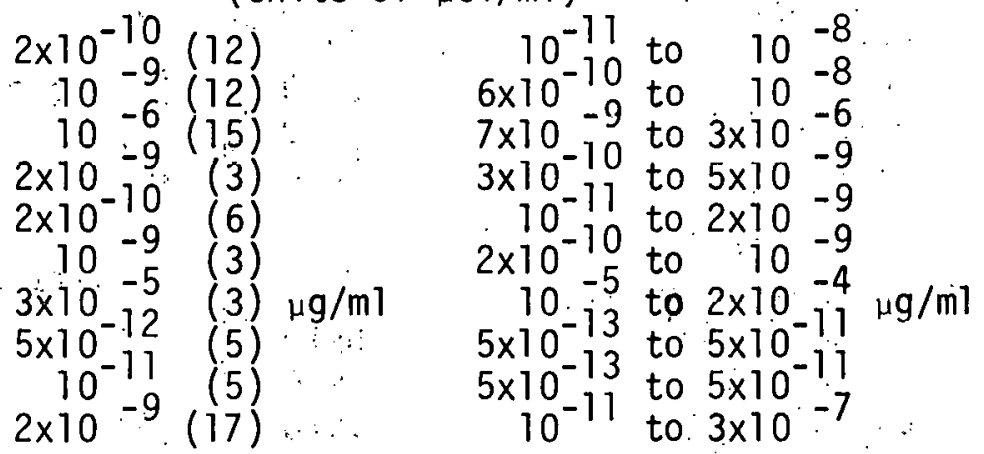

(Units of $\mu \mathrm{Ci} / \mathrm{g}$ )

$\begin{array}{rrrr}10^{-7} & (3) & 5 \times 10^{-8} \text { to } 10^{-6} \\ 3 \times 10^{-7} & (3) & 2 \times 10^{-7} \text { to } 3 \times 10^{-6} \\ 4 \times 10^{-9} & (2) & 3 \times 10^{-11} \text { NA } \text { to } 5 \times 10^{-6} \\ 3 \times 10^{-9} & (4) & 4 \times 10^{-10} \text { to } 3 \times 10^{-8} \\ 3 \times 10^{-9} & (5) & 3 \times 10^{-8} \text { to } 2 \times 10^{-6}\end{array}$

*The minimum detectable levels are those reported for the concentrations and mixtures of radionuclides routinely encountered in the environmental media shown. "Typical" values are those most often reported for the analytical procedures and counting equipment used, as reported in Tables through of this summary. The numbers shown in parentheses refer to the number of sites whose detection limits were used to obtain the "typical" and "range" values. The lower detection limits are typically for samples containing only a single radionuclide; i.e., following radiochemical separation and/or sample enrichment prior to counting. The higher detection limits probably represent a combination of factors such as smaller sizes and more complex mixtures of radionuclides.

* Multichannel analyzer with either a $\mathrm{NaI}(\mathrm{Tl})$ or $\mathrm{Ge}(\mathrm{Li})$ detector; typical nuclides include: Co-60, 58; Zn-65; ZrNb-95, Cs-137, and $\mathrm{Ce}-144,141$ (soil, sediment, and vegetation), plus Ru-106, 103; and $\mathrm{Ba}-\mathrm{La}-140$ (air), and $\mathrm{Cr}-51$ (water). 
TABLE 18. (contd)

$$
\begin{aligned}
& \text { Milk } \\
& \text { Sr-89 } \\
& \text { Sr-90 } \\
& \text { I-131 } \\
& \text { Cs- } 137
\end{aligned}
$$

Vegetation

Gross Alpha

Gross Beta

H-3 (HTO)

$\mathrm{Sr}-90$

U-Total

Pu-239

Gamma Scan

Fish, Meat, Poultry

Co-60

$\mathrm{Sr}-90$

Cs -1.37
Minimum Detectable Levels*

Typical

Range

(Units of $\mu \mathrm{Ci} / \mathrm{ml}$ )

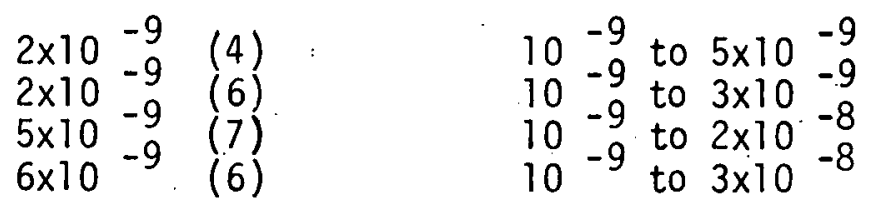

(Units of $\mu \mathrm{Ci} / \mathrm{g}$ )

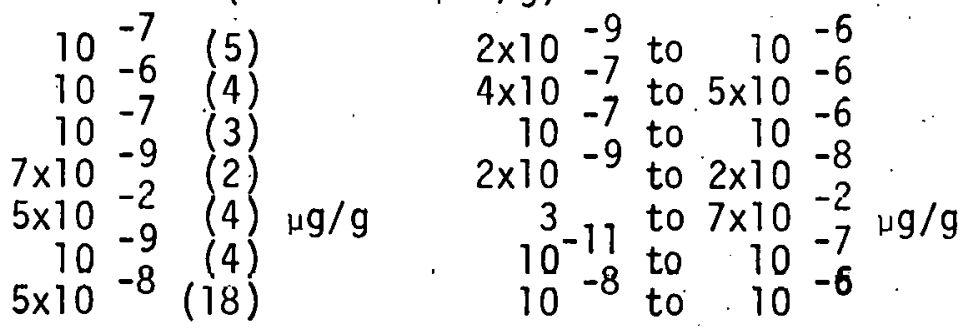

(Units of $\mu \mathrm{Ci} / \mathrm{g}$ (wet weight)

$\begin{array}{lll}5 \times 10^{-8} & (4) & 10^{-8} \text { to } 2 \times 10^{-7}: \\ 2 \times 10^{-9} & (2) & 10^{-8} \text { NA } 2 \times 10^{-7} \\ 5 \times 10^{-8} & (5) & \text { to }\end{array}$


TABLE 19. Summary of AEC Environmental Surveillance Comparability*

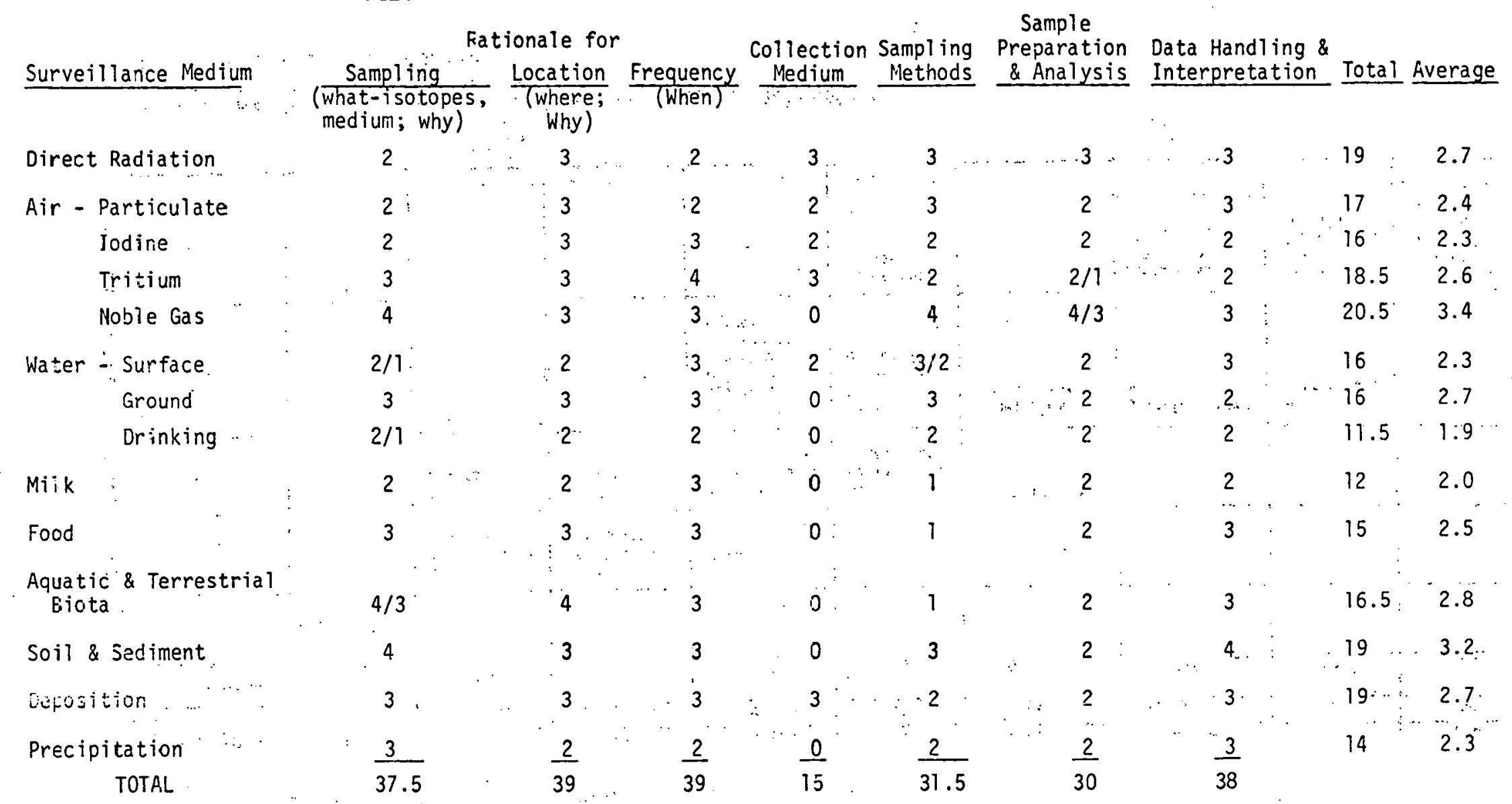

*The values shown in the table indicate the relative level of knowledge (based on experience) and the consistency of techniques, according to the following numberirg system:

0 - Not applicable (i.e., when the sampling mediunı used does not further concentrate the sample).

1 - No problems areas encountered.

2 - Criteria, methods, etc. are reasonably standardized.

3 - Some uniformity or consistency, but sone questions still remain.

4 - Definitely needs further study (acceptable methods and/or criteria are insufficient or totally lacking). 


\section{TABLE 20. Sugges-ec Ranking of Environmental Media as a Function of Effluent Pathway and Identity}

\begin{tabular}{|c|c|c|c|c|c|c|c|c|c|}
\hline $\begin{array}{l}\text { Effluert Pathway } \\
\text { Radionsclide(s) }\end{array}$ & $\begin{array}{l}\text { Air } \\
\text { Motie Gis* }\end{array}$ & $\frac{\text { Air }}{\text { Tritium }}$ & $\frac{\text { Air }}{\text { Iodine i131) }}$ & $\frac{\text { Water }}{\text { MFp }}$ & $\frac{\text { Air }}{\text { MEP }}$ & Water & Water & $\frac{\text { Air }}{T^{+}}$ & inter \\
\hline Typical Releases & $n^{4}-7^{5}$ & 4.5 & & & & Iritium & 100ine $(131)$ & & \\
\hline & 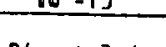 & $10-10$ & 1.5 & $1-10$ & $1-5$ & $5 \times 10^{3}-5 \times 10^{4}$ & $1-5$ & $10^{-3}$ & 0.1 \\
\hline 5 & $\begin{array}{l}\text { ofrect Rad. } \\
\text { hir - NG }\end{array}$ & & & & & & & & \\
\hline$\frac{\bar{u}}{z}$ & & $\begin{array}{l}\text { Air H-3 } \\
\text { Preciptation } \\
\text { Vegetables }\end{array}$ & $\begin{array}{l}\text { Mill. } \\
\text { Vege:tables } \\
\text { Air lodine }\end{array}$ & F1sh & & . & & & \\
\hline 3 & $\cdot$ & $\begin{array}{l}\text { Native } \\
\text { Grasses }\end{array}$ & Foräze & $\begin{array}{l}\text { Wa:erfowl } \\
\text { Susface Water } \\
\text { Milk }\end{array}$ & $\begin{array}{l}\text { Air } \\
\text { Particulates } \\
\text { Vegetables }\end{array}$ & $\begin{array}{l}\text { Drinking and } \\
\text { Surface Water }\end{array}$ & & & \\
\hline 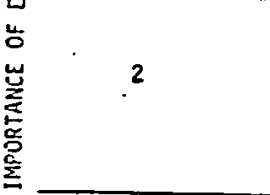 & & . & & $\begin{array}{l}\text { Df:oct/Soli } \\
\text { Sedinent } \\
\text { Orinking } \\
\text { Groundwater } \\
\text { Terrestrial } \\
\text { Animals }\end{array}$ & $\begin{array}{l}\text { Milk } \\
\text { Solf } \\
\text { Deposition } \\
\text { Direct Rad. }\end{array}$ & $\begin{array}{l}\text { Vogetables } \\
\text { Groundwater }\end{array}$ & $\begin{array}{l}\text { Orinking Water } \\
\text { Mi:k }\end{array}$ & $\begin{array}{l}\text { Alr } \\
\text { Particulates }\end{array}$ & \\
\hline 岂 & & & & & $\begin{array}{l}\text { Vegetables } \\
\text { Forage }\end{array}$ & & $\begin{array}{l}\text { Surface Water } \\
\text { Vegetables } \\
\text { Forage }\end{array}$ & $\begin{array}{l}\text { Deposition } \\
\text { Soll } \\
\text { Terrestrial } \\
\text { Animals }\end{array}$ & $\begin{array}{l}\text { Fish } \\
\text { Vucciables } \\
\text { Surfare } 8 \\
\text { orinking } \\
\text { hidtir } \\
\text { Sodinent }\end{array}$ \\
\hline
\end{tabular}

- Frimerily ar-4 (r.r 5 Xe 3 re dpprox an order of magnitude less, 1.e., $\left.10^{3}-4 \times 10^{3} \mathrm{Cl} / \mathrm{y}\right)$

"Transuranic nuclides (arinarily. Pu-239). 
TABLE 21. Environmental Surveillance Comparability

$\therefore \quad$ Weighted by Radiation Do se

Surveillance Media

Air - Noble Gas.

Direct Radiation

Air - Tritium

Foods

Air - Iodine

Precipitation

Aquatic.\& Terrestrial Biota

Milk

Air Particulates

Surface Water

So il/Sediment

Drinking Water

Groundwater

Deposition
Weighted Factor*

$17 \cdot \cdots: \div$

14

10

10

9.2

9.2

8.4

8.0

7.2

6.9

6.4

5.7

5.4

5.4

\#eighted Factor $=$ Average $($ Tabje 19) $\times$ Relative importance $($ Table 20) 
TABLE 22. Suggested Environmental R\&D Priorities

1. Methods, analysis, and interpretation of direct radiation measurements.

2. Atmospheric tritium sampling media (and frequency).

3. Rationale of sampling, location, frequency and species for aquatic and terrestrial biota.

4. Rationale of soil sampling and interpretation (and methods).

5. Rationale, methods, location, frequency, and interpretation of deposition sampling.

(The above categories will require some experimental research.)

6. Rationale of sampling, location, and frequency for foodstuffs (including data handling and interpretation).

7. Location and frequency of sampling for atmospheric iodine.

8. Sampling methods and locations for airborne particulates.

9. Methods, location, and frequency for sampling groundwater.

10. Methods and frequency of sampling surface water.

(The amount of experimental research needed for items $6-10$ is judged to be limited, and in some cases not required.)

NOTE: While noble gas sample collection, preparation, and analysis would appear to be very important, it is believed to be of minor significance in light of the "indirect" methods available in direct radiation measurement. 


\section{Discussion Outline}

ENVIRONMENTAL SURVEILLANCE \& EFFLUENT MONITORING AT AEC CONTRACTOR SITES

I. Standards and Criteria for Environmental Surveillance
A. AECM 0524 - Population Criteria; Concentration Guides; or Release Limits.
B. Other Guides or Criteria.
C. Derived Working Levels.

\section{Dose Evaluation}

A. Air Dispersion

1. Is meteorological model in routine use? Describe model used.

2. Sources of meteorological information?

B. Water Dispersion

1. Is hydrological model in routine use? Describe modei used.

2. Sources of hydrological information?

C. Dose Model

1. Is population dose calculated?

2. Components of dose model?

3. Quantities and sources of information:

a. Diet (milk, water, foodstuffs).

b. Wildlife (fish, game, wildfowl).

c. Occupancy factors:

4. Lung model used? 
III. Environmental Surveillance Program Design

A. Location

1. Are locations of air and water sampling stations related to models described?

2. Other rationale for determining numbers and locations of stations?

B. Media sampled, frequency, and analyses requested.

1. Relationship to dose model?

2. Rationale of trequency and type of measurement or sample and analyses.

a.: Afr - Particulate, noble gas, tritium, radioiodine.

b. Water. - Surface water, groundwater.

c. Milk.

d. Vegetation

e. Fish, game, wildfowl, other foodstuffs

f. Soit/Sediment

g. External exposure - terrestrial, aquatic.

IV. Techniques \& Procedures

For each medium (see list in III above) under each subhead, describe rationale and include documentation it avajlable.

1. Equipment used, including vendor information.

2. Special procedures and precautions used in collecting and holding samples and táking measurements.

3. Analytical equipment and procedures used -- is this work subcontracted? 
V. Routine Effluent Measurements

1. Is effluent data from this source used to estimate environmental concentrations or population dose?

2. Is sample or monitoring stream flow rate proportional to effluent flow rate?

3. Is sample or monitoring stream flow designed to be representative of entire effluent stream?

4. Is particle size determination made (gaseous effluents only)?

5. Are radioanalyses made routinely by another agency than, the operating contractor?

6. Normal effluent flow rate?

Frequncy of measurement?

Sample flow rate?

7. Sensitivity per nuclide -- minimum detectable concentration, measurable range, instrumentation sampled or monitored (continuous or intermittent)?

8. DOS Effluent Information System Code?

VI. Quality Control \& Statistical Analysis

1. Describe quality control program, including audits and calibration.

2. Are control charts routinely maintained for calibrations and audits? For field results? If yes, describe derivation and use.

3. Describe action guides for environmental and effluent measurements, and planned actions:

\section{Reporting}

1. Describe routine manipulation of data - compositing, averaging, analyzing for variability.

2. Frequency and type of routine reports? 


\section{References}

1. Copy or document number of most recent environmental report(s).

2. Copies or list of document numbers of directly applicable topical reports.

\section{$7 / 25 / 73$}

Dale H. Denham

Battelle

Pacific Northwest Labs. 
BNWL-B-384

\section{APPENDIX B \\ SUMMARY OF EFFLUENT MONITORING PARAMETERS \\ FOR SELECTED STREAMS AT AEC SITES}

As for the tables in the body of this report, the numbers shown in each category and classification will differ from table to table, both because more than one kind of measurement is made on a particular effluent stream and because some data was not readily available. 
TABLE B-1. Summary of Effluent Monitoring Techniques at Selected AEC Contractor Installatiors - Air, Particulates

(17 Installatiors)

\begin{tabular}{ll} 
Collecting Medium. & \\
\hline Cellulose & 3 \\
Cellulose/Asbestos & 9 \\
Glass fiber & 3 \\
Membrane & 2 \\
Moving filter tape & 3
\end{tabular}

$\infty$
1
$N$

\begin{tabular}{ll} 
Arialytical Frequency & \\
\hline Continuous & 3 \\
$0-50$ per year & 2 \\
$501-100$ per year & 5 \\
$100-200$ per year & 1 \\
$>200$ per year & 6
\end{tabular}

\section{Sample Col'ection \\ Proportional to flow Not proportional to flow \\ $\epsilon$ \\ Typical Minimum Detectable Levels}

\begin{tabular}{|c|c|}
\hline & \\
\hline Gross alpra ànd beta & $10^{-7}$ to $5 \times 10^{-3} \mu \mathrm{Ci} / \mathrm{cc}$ \\
\hline Gross beta and gamma ( $\mathrm{NaI}$ ) & $3 \times 10^{-8}$ to $6 \times 10^{-4} \mu \mathrm{Ci} / \mathrm{cc}$ \\
\hline GM viewed tape & $5 \times 10^{-10}$ to $3 \times 10^{-8} \mu \mathrm{Ci} / \mathrm{cc}$ \\
\hline 1pha scar (scilid state) & $10^{-12}$ to $2 \times 10^{-8} \mu \mathrm{Ci} / \mathrm{cc}$ \\
\hline & $10^{-8}$ to $2 \times 10^{-5} \cdot \mu \mathrm{Ci} / \mathrm{cc}$ \\
\hline
\end{tabular}

\section{Analys is Performed}

Gamma scan

Gross alpha and beta

Gross beta and gamma

Alpha. scan 
TABLE B-2. Summary of Effluent Monitoring Techniques at Selected AEC Contractor Installations -

Air, Tritium

(9 Installations)

Collecting Medium

Monitored but not sampled

Silica gel

Molecular sieve

Cold trap

Dehumidifier

Analytical Instrumentation

Kanne Chamber

Ion Chamber

Liquid Scintillation

Analytical Frequency

Continuous

$<10$ per year

$>50$ per year

Data unavailable

When indicated by monitoring

Typical Minimum Detectable Levels *Kanne Chamber $5 \times 10^{-6}$ to $6 \mu \mathrm{Ci} / \mathrm{cc}$

*Ion Chamber $10^{-7}$ to $9 \times 10^{-5}$

Liquid $2 \times 10^{-13}$ to $10^{-10} \mu \mathrm{Ci} / \mathrm{cc}$ Scintillation

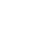

क्

6

*Range of response 
TABLE B-3. Summary of Effluent Monitoring Techniques at Selected AEC Contractor Instaliations Air, Iodine

\section{(7 Installations)}

Collecting Medium

Charcoal 5

Scrubber $\quad \cdot 2$

\section{Analytical Frequency \\ 0-50 per year \\ 50-100 per year 2 \\ 100-200 per year \\ $>200$ per year 2 \\ Data not available 2}

Analys is Performed

Gamma Scan 5

Gross Count 2

Typical Minimum Detectable Leve1

Gamma SCan $5 \times 10^{-15}$ to $10^{-13} \mu \mathrm{Ci} / \mathrm{CC}$


TABLE B-4. Summary of Effluent Monitoring Techniques at Selected AEC Contractor Installations -

Air, Noble Gas

\section{(8 Installations)}

Collecting Medium

Monitored but not sampled 5

Vacuum flask 2

Releases calculated 1

Analytical Frequency

$>15$ per year 1

$<50$ per year 1

Analytical Instrumentation

GM in stack

$\mathrm{NaI}$ in stack

1

Geli in laboratory

1

Typica. Minimum Detectable Levels

GM in stack $2 \times 10^{-7}$ to $2 \times 10^{-3} \mu \mathrm{Ci} / \mathrm{cC}$

Flow through $10^{-4}$ to $5 \times 10^{-3} \mu \mathrm{Ci} / \mathrm{cc}$

ion chamber

$\mathrm{NaI}$ in stack $2 \times 10^{-6}$ to $4 \times 10^{-3} \mu \mathrm{Ci} / \mathrm{cc}$ 
TABLE B-5. Summary of Effluent Monitoring Techniques at Selected AEC Contractor Installations - Liquid

(17 Insta1lations)

\section{Collection Technique}

Grab

Ion Exchange

Continuous-proportiona?

Continuous-non-proportional

\section{Analytical Frequency}

\section{.}

Continuous

0-50 per year

50-100 per year

100-200 per year

$>200$ per year

per batched reliased

\section{Analyses Performed}

Gamma scan 5

Gross alpha and beta 6

Grass beta and gamma 1

Alfha scan 2

Dissolved versus suspended 2

Liquid Scintallation 3

Uranium

4

Typical Minimum Detection Levels

Gamma Scan $\quad 10^{-11}$ to $3 \times 10^{-7} \mu \mathrm{Ci} / \mathrm{cc}$

Gross beta and gamma

$10^{-10}$ to $10^{-8} \mu \mathrm{Ci} / \mathrm{cc}$

Gross alpha and beta $10^{-11}$ to $10^{-8} \mu \mathrm{Ci} / \mathrm{cc}$

*U fluorometric

$10^{-9}$ to $10^{-1} \mu \mathrm{Ci} / \mathrm{cc}$

Liquid scintillation

Alpha scan

7. $\times 10^{-9}$ to $3 \times 10^{-6} \mu \mathrm{Ci} / \mathrm{cc}$

$5 \times 10^{-13}$ to $5 \times 10^{-11} \mu \mathrm{Ci} / \mathrm{cc}$

*Range of response 
BNWL-B-384

Special Distribution

in Category UC-41

\section{DISTRIBUTION}

No. of

Copies

1 AEC Chicago Patent Group

U.S. Atomic Energy Commission

Argonne, IL 60439
A. A. Churm

1 AEC Headquarters

Division of Operational Safety

Germantown, Maryland

M. W: Tiernan

27 AEC Technical Information Center

43 Attendees and Contacts of "Environmental Surveillance Methodology Workshop"

Kenneth E. Apt

Los Alamos Scientific Lab., H-8

Los Alamos; NM

M. Awschalom

National Accelertor Lab

Batavia, IL

Wayne A. Bliss

EPA, Nat'1 Environmental Res. Ctr.

Las Vegas, NV

Donald A. Busick

Stanford Linear Accelerator Ctr.

Stanford, CA

Franklin E. Coffman

$A E C$, Div: of Operational Safety

Germantown, MD

John P. Corley

Battelle

Pacific-Northwest Labs.

Richland, WA

Todd V. Crawford

Savannah River Laboratory

Aiken, SC

Doyle M. Davis

Oak Ridge National Lab

Oak Ridge; TN

Dale H. Denham

Radiation Management Corp.

Philadelphia, PA
Goff H. Giboney

USAEC, Savannah River Operations Office

Aiken, SC

Wayne C. Hanson

Los Alamos Scientific Lab., $\mathrm{H}-8$

Los Alamos, NM

Andy P. Hull

Brookhaven National Lab.

Upton, NY

Fred B. Johns

EPA, Nat' 1 Environmental Res. Ctr. Las Vegas, NV

LaMar J. Johnson

Los Alamos Scientific Lab, H-8

Los Alamos, NM

George Kirche

Battelle-Columbus

Columbus, $\mathrm{OH}$

Walt L. Marter

Savannah River Plant

Aiken, SC

H. A. Mc Clearen

Savannah River Lab.

Aiken, SC

Jack D. McLendon

Y-12 Plant

Oak Ridge, TN 
No. of

Copies

Attendees and Contacts (contd)

Don E. Michels

Aerojet Nuclear Company

Thomas Steele

Idaho Falls, ID

LaCrosse BWR

Lacrosse, WI

Ray L. Miller

Albuquerque Operations Office, AEC

Albuquerque, NM

John D: Moore

Atomics International

Calluga Park, CA

Arthur A. Schoen

AEC; Div, of Mperraliomal Safety

Germantown, MD

Jacob. Sedley

Argonnc National Lab.

Argonne, IL

Billy D. Shipp

AEC, Chicago Operations Office

Argonne, IL

Bill J. Siliver

Lawrence Livermore Lab.

Livermore, $C A$

Neil B. Schultz

Oakridge Gaseous Diffusion Plant

Oak Ridge, TN

Lloyd D. Stephens

Lawrence Berkeley. Laboratory

Berkeley, CA

James. G. Stearns

USAEC, Rocky Flats Area Office

Golden, CO

M. A. Thompson

Dow Chemical USA

Rocky Flats Plant

Golden, C0

Herbert L. Volichok

$\Lambda \mathrm{EC}$; Heailth \& Satety Lạh.

New York, NY

Milo D. Voss

Ames Laboratory

Ailles, Iowa

David A, Waite

Battelle

Pacific-Northwest Lab.

Richland, WA

Don I. Walker

USAEC, Health Services Lab.

Idaho Falls, ID

Winston E. Ward

General Electric Company

St. Petersburg; 'FL

Carl Welty

AEC, Division of Operational Safety

Germantown, MD

George Werkema

Dow Chemical USA

Rocky Flats Plant

Golden, : CO

Robert L. Westby

USAEC, San Francisco Operations Office

San Francisco, CA 
No. of

Copies

Attendees and Contacts (contd)

William Westendorf

Monsanto Res. Lab. -Mound Lab.

Miamisburg, Ohio

Merle Wheeler

Los Alamos Scientific Lab.

Los Alamos, NM

Arthur J. Whitman

USAEC, Nevada Operations Office

Las Vegas, NV

Jerry $F$. Wing

USAEC, Oak Ridge Operations Office

Oak Ridge, TN

John Zillich

Dow Chemical USA

Rocky.Flats Plant

Golden, CO

3 AEC-RL Patent Attorney

B. J. Melton

R. B. Goranson (2)

1. AEC Richland Operations Office

P. G. Rhoades

$15 \therefore$ Battelle-Northwest

J. P. Corley (10)

H. V. Larson

C. M. Unruh

Technical Information Files (2)

Technical Publications 